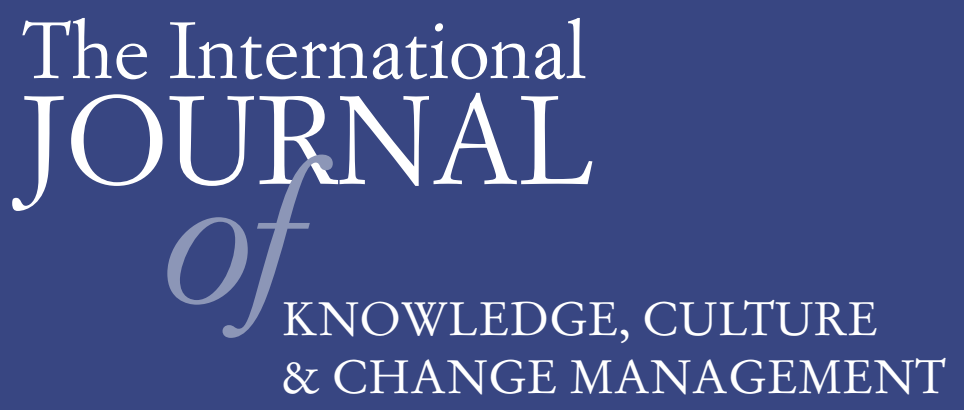

Volume 9, Number 5

A Contribution to Transparency of Scientific and Engineering Concepts

K. Abhary, H. K. Adriansen, F. Begovac, Z. Kovacic, C. N. Shpigelman, C. Stevens, S. Spuzic, F. Uzunovic and K. Xing 


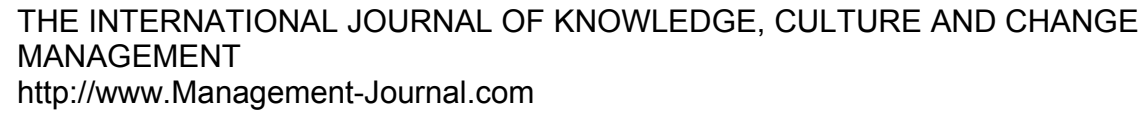

First published in 2009 in Melbourne, Australia by Common Ground Publishing Pty Ltd www.CommonGroundPublishing.com.

(C) 2009 (individual papers), the author(s)

(c) 2009 (selection and editorial matter) Common Ground

Authors are responsible for the accuracy of citations, quotations, diagrams, tables and maps.

All rights reserved. Apart from fair use for the purposes of study, research, criticism or review as permitted under the Copyright Act (Australia), no part of this work may be reproduced without written permission from the publisher. For permissions and other inquiries, please contact

<cg-support@commongroundpublishing.com>.

ISSN: 1447-9524

Publisher Site: http://www.Management-Journal.com

THE INTERNATIONAL JOURNAL OF KNOWLEDGE, CULTURE AND CHANGE MANAGEMENT is peer-reviewed, supported by rigorous processes of criterionreferenced article ranking and qualitative commentary, ensuring that only intellectual work of the greatest substance and highest significance is published.

Typeset in Common Ground Markup Language using CGCreator multichannel typesetting system

http://www.commongroundpublishing.com/software/ 


\title{
A Contribution to Transparency of Scientific and Engineering Concepts
}

\author{
K. Abhary, University of South Australia, Australia \\ H. K. Adriansen, University of Aarhus, Denmark \\ F. Begovac, University of Zenica, Bosnia and Herzegovina \\ Z. Kovacic, Open Polytechnic of New Zealand, New Zealand \\ C. N. Shpigelman, Universtiy of Haifa, Israel \\ C. Stevens, Imperial College London, UK \\ S. Spuzic, University of South Australia, Australia \\ F. Uzunovic, University of Zenica, Bosnia and Herzegovina \\ K. Xing, University of South Australia, Australia
}

\begin{abstract}
Knowledge management is of outmost importance in organisations. This treatise aims to contribute in improving the transferability and transparency of some basic concepts relevant to science, education and engineering. Knowledge sharing can be adversely affected by concepts and specific terms which are in common use but can vary in meaning. Since contemporary technological issues typically involve several disciplines it would be useful to analyse areas where effective communication and transfer of knowledge between academic and engineering disciplines might benefit from clarification. Examples of concepts that impede knowledge sharing are identified and mitigating strategies proposed.
\end{abstract}

Keywords: Knowledge, Cross-disciplinary, Education, Transferability

\section{Introduction}

$\mathrm{D}$ IGITRONIC SYSTEMS HAVE helped to manipulate (store, retrieve and share) the body of scientific knowledge and make it available, via the internet, on a global scale. The 21 st century knowledge society enjoys the fruits of scientific progress including the use of modern materials such as "smog-eating cement" and nanoscale structured solar sheets, delivered and maintained by complex industrial systems and terotechnology equipped with automatons and artificial intelligence. Medical sciences have extended our ability to fight disease and engineering endeavours have literally reached the sky in the case of space projects.

It is not easy to distinguish when academe drives and when it follows the waves in the rising oceans of knowledge, but it is clear that the proliferation of new terms and the adaptation of established concepts to fit a new use can provide a formidable obstacle to learners and users. Sound acquisition and understanding of science cannot be achieved by a 'silo' approach that accumulates an ever-increasing volume of knowledge whose language is not clearly understood. The capacity to manage knowledge is increasingly important for the

The International Journal of Knowledge, Culture and Change Management

Volume 9, Number 5, 2009, http://www.Management-Journal.com, ISSN 1447-9524

(c) Common Ground, K. Abhary, H. K. Adriansen, F. Begovac, Z. Kovacic, C. N. Shpigelman, C. Stevens,

S. Spuzic, F. Uzunovic, K. Xing, All Rights Reserved, Permissions:

cg-support@commongroundpublishing.com 
development of a sustainable society. To build this capacity, a knowledge database must include not only relevant information but also a strategy for making connections between disparate concepts (Klingner \& Sabet, 2005).

This treatise aims to contribute to improving the mobility and transferability of crossdisciplinary knowledge. It builds on previous discourses (Abhary et al., 2009; Spuzic, Xing \& Abhary, 2008) where the theoretical foundations were presented, and isolates four examples, 'vector', 'structure', 'logistic' and 'technology' to illustrate how such terms can impede the sharing and application of knowledge. The ambiguous aspects of these terms are discussed and mitigating strategies are proposed.

\section{Impediments to Knowledge Transferability}

When presenting knowledge, it is important to have in mind the ultimate recipients. Academic efforts to categorise sub-domains of knowledge into formal disciplines have certainly improved the understandability of the enormous variety of phenomena.

However, this vivisection of the body of knowledge has also raised some barriers. Recent trends in engineering and sciences calling for better communication between what traditionally have been regarded as distinct disciplines have uncovered conceptual mismatches in a crossdisciplinary transfer of knowledge.

There has always been a delay between making new discoveries and organising the nomenclature which allows others to share and use that knowledge. This has been exacerbated by the recent increase in the quantity of new discoveries and their possible applications, and by the need for students to adopt a cross-curricular approach to their learning. There is thus a growing need to review and edit the knowledge records. One approach to this is in the improvements in information processing. However, in spite of the promise of the Semantic Web (Shadbolt, Berners-Lee \& Hall, 2006) and developments in the search engines (intelligent agents and bots in particular), artificial intelligence may also lead into labyrinths that mingle both useful and irrelevant information.

Merely collecting information is not sufficient for knowledge utilisation. Analysis and synthesis are necessary along with a comparative scrutiny of deduced and inferred conclusions. Advanced university curricula require cross-disciplinary knowledge without an excessive volume of nomenclatures. We understand things by generalising relationships, creating a hierarchy of information, selecting significant factors out of many possible interactions, and by visualising analogies. Depending on our intentions, beliefs and knowledge, we create models and make decisions. But the final proof of validity lies in a successful application of relevant knowledge. This 'final' step underlies the importance of cross-disciplinary transfer and application of knowledge.

This potential can be substantially undermined by ambiguous or even conflicting definitions of essential concepts. In addition to confusion in the operation of cross-disciplinary systems, ambiguous concepts hinder the flow of knowledge during the educational process. There is a growing body of evidence which indicates that there can be a serious disruption to a learner's progress when confronted by apparent contradictions of meaning. Reasoning modality is related to perceptions of similarity, which can be blunted by conceptual misalignments and terminological inconsistencies (Abhary et al., 2009); Problems related to ambiguous interpretations of concepts have been addressed by a number of researchers as can be seen in the 
extensive bibliography maintained by Princeton University (Cognitive Science Laboratory, 2007).

Table 1 presents examples of such ambiguities.

Table 1: Examples of Ambiguous Concepts (see http://tableA.synthasite.com for more examples)

\begin{tabular}{|c|c|}
\hline Paraphrase & Corresponding Definition \\
\hline $\begin{array}{l}\text {...sprays that distribute the vector in the nasal } \\
\text { cavity. (Csaba, Garcia-Fuentes \& Alonso, 2008) }\end{array}$ & \multirow{2}{*}{$\begin{array}{l}\text { Clause 1. Vector is a transmitter - any } \\
\text { agent, person, animal, microorganism, } \\
\text { DNA molecule - that carries and transmits } \\
\text { a genetic material (e.g. causing an infec- } \\
\text { tion). }\end{array}$} \\
\hline $\begin{array}{l}\text {...within their vector mosquitoes. (Perera et al., } \\
\text { 2008) }\end{array}$ & \\
\hline “direction vector" (Steeman et al., 2009) & \multirow[b]{2}{*}{$\begin{array}{l}\text { Clause 2. Vector is an ordered i-tuple of } \\
\text { numbers, where } \mathrm{i}=\text { a natural number. }\end{array}$} \\
\hline $\begin{array}{l}\text { Anand, Pugalenthi \& Suganthan (2008) per- } \\
\text { formed a detailed comparison of various methods } \\
\text { and different feature vectors. }\end{array}$ & \\
\hline $\begin{array}{l}\text { Giancaspro et al. (2009) reported the use of FRP } \\
\text { (fiber-reinforced polymer) composites in the re- } \\
\text { habilitation of reinforced concrete structural } \\
\text { components. FRP composites are applied to a } \\
\text { variety of structural members including beams, } \\
\text { columns, walls and aerospace structures. }\end{array}$ & \multirow{2}{*}{$\begin{array}{l}\text { Clause 3. Structure is made of mechanic- } \\
\text { al solid components (such as steel beams } \\
\text { and bars, concrete columns or other con- } \\
\text { struction engineering components). }\end{array}$} \\
\hline $\begin{array}{l}\text {...the wind power generator structure/structur- } \\
\text { al cost. (Li \& Chen, 2009) }\end{array}$ & \\
\hline $\begin{array}{l}\text { Steeman et al. (2009) use the expression 'the } \\
\text { building structure' but later states that 'the room } \\
\text { is discretized using a structured hexahedral } \\
\text { grid, to limit the computational time.' }\end{array}$ & \multirow{4}{*}{$\begin{array}{l}\text { Clause 4. Structure of something is which } \\
\text { and how its parts (components) are put to- } \\
\text { gether. }\end{array}$} \\
\hline $\begin{array}{l}\text { The prediction of protein structural class is an } \\
\text { important component of the protein structure } \\
\text { prediction. (Anand, Pugalenthi \& Suganthan, } \\
\text { 2008) }\end{array}$ & \\
\hline $\begin{array}{l}\text { A technology has to have a } 10 \text { to } 1 \text { cost advant- } \\
\text { age to have a chance to alter the existing struc- } \\
\text { ture of an industry. (Elias, 1998) }\end{array}$ & \\
\hline $\begin{array}{l}\text { Hsu et al. (2008) present a crystal structure of } \\
\text { cycle inhibiting factor. }\end{array}$ & \\
\hline
\end{tabular}




\begin{tabular}{|c|c|}
\hline $\begin{array}{l}\text { "...the supply and distribution activities if integ- } \\
\text { rated with the manufacturing / logistic activities, } \\
\text { can result in better profitability for the organisa- } \\
\text { tion." ("Logistic engineering" in "Wikipedia", } \\
\text { 2009) }\end{array}$ & $\begin{array}{l}\text { Clause 5. Logistic (adjective) is relating } \\
\text { to "logistics' (Here "logistics "is "... the } \\
\text { management of the flow of ... resources } \\
\text {... between the point of origin and the } \\
\text { point of consumption..." ("Logistics" in } \\
\text { "Wikipedia", 2009) }\end{array}$ \\
\hline $\begin{array}{l}\text { "The logistic function finds applications in a } \\
\text { range of fields, including artificial neural net- } \\
\text { works, biology, biomathematics, demography, } \\
\text { economics, chemistry, mathematical psychology, } \\
\text { probability, sociology and statistics." ("Logistic } \\
\text { function" in "Wikipedia", 2009) }\end{array}$ & $\begin{array}{l}\text { Clause 6. A logistic function or logistic } \\
\text { curve is the most common sigmoid curve. } \\
\text { It models the S-curve of growth of some } \\
\text { set. }\end{array}$ \\
\hline $\begin{array}{l}\text { Universal character (i.e. an universal and formal } \\
\text { language) would have to serve as symbolism for } \\
\text { the exact and systematic expression of all present } \\
\text { knowledge, making possible a logistic treatment } \\
\text { of science in general. (Cohen, 1954) }\end{array}$ & $\begin{array}{l}\text { Clause 7. Logistic (adjective) is related to } \\
\text { 'logistic' (noun) which "may be defined } \\
\text { as the science which deals with types of } \\
\text { order as such." (Lewis, 1960) }\end{array}$ \\
\hline $\begin{array}{l}\text { Technology is 'the science of the application of } \\
\text { knowledge to particular purposes'. (Strawn, } \\
1982 \text { ) }\end{array}$ & $\begin{array}{l}\text { Clause 8. Technology is the science of } \\
\text { techniques. }\end{array}$ \\
\hline $\begin{array}{l}\text { The pier caps exhibited severe cracking and were } \\
\text { considered for strengthening using fiber-rein- } \\
\text { forced polymer technology. (Giancaspro et al., } \\
\text { 2009) }\end{array}$ & \multirow{2}{*}{$\begin{array}{l}\text { Clause 9. Technology denotes techniques } \\
\text { including the pertinent materials, tools, } \\
\text { equipment and other means (e.g. lubric- } \\
\text { ants, energy providing media) for achiev- } \\
\text { ing certain pre-defined aim. }\end{array}$} \\
\hline $\begin{array}{l}\text { Synthetic Biomimetic Supramolecular Biovector } \\
\text { is a proprietary technology developed by a } \\
\text { French company. (Csaba, Garcia-Fuentes \& } \\
\text { Alonso, 2008) }\end{array}$ & \\
\hline
\end{tabular}

\section{Vector}

The definition provided in Table 1 (Clause 2) is complemented by special descriptions of vector as:

- "a geometric object, or a straight line segment whose length is magnitude and whose orientation in space is direction" (Cognitive Science Laboratory, 2009 and Wikimedia Foundation, 2009), and

- (Wikimedia Foundation, 2009).

However, a differing definition (Clause 1, Table 1) appearing in medicine, biology, ecology and genetics allows for interpreting the concept of vector as:

- any vehicle used to transfer foreign genetic material into another cell (Cognitive Science Laboratory, 2009); 
- an organism which transmits infection by conveying pathogens from one host to another (Wikimedia Foundation, 2009).

This conceptual mismatch could create confusion especially when applying vector based mathematics for example in communication involving civil engineering, epidemiology, molecular biology or environmental engineering. Concrete walls are constructed based on principles of statics, where the idea of "vector" presents one of the fundamental concepts. Such walls can be built with cement containing an agent that breaks air pollutants through a photocatalysis. A photocatalyser $\left(\mathrm{TiO}_{2}\right)$ when incorporated in cement hastens the decomposition of organic and inorganic pollutants ("vectors") and prevents their build-up on surfaces (Wagner, 2006; Amadelli et al., 2005). In this context the term 'vector' can imply very differing concepts to civil engineers trying to communicate with environmental engineers.

\section{Structure}

'Structural engineering' is introduced as a discipline dealing with the analysis and design of structures that support or resist loads. It is often considered a specialty within civil engineering, but can also be studied as a discrete discipline (University of San Diego, 2008). Structural engineers are involved in the design of buildings and large non-building structures, but also in the design of machinery, medical equipment, vehicles or any item where structural integrity affects the item's function (Wikimedia Foundation, 2009; Institution of Structural Engineers, 2008). Yet other sources relate the concept of 'structure' to public (bridges, tunnels) and industrial (silos, tanks, platforms, supermarkets) infrastructures and use expressions such as 'structural sections' and 'structural steel' (Abhary et al., 2008). From an etymological point of view, the concept of 'structure' is well linked to the above definitions. However, this concept has outgrown its historical roots and today the concept of 'structure' is used within a broad range of scientific and engineering contexts, as shown in Table 1. For example, the concept of 'structure' is used in materials science to address both the geometric topography and a variety of other chemo-physical phenomena within solids. Terms such as 'microstructure', 'macrostructure' and 'nanostructure' are broadly used in the physics of solids and related disciplines (Abhary et al., 2008; Biaggi-Labiosa et al., 2008).

Let as analyse an example of a misleading usage of the term 'structural': The 'Tissu Fibre de Carbone' procedure results in structural reinforcement by the adhesion of carbon-fibers to a binding matrix of a bi-component epoxy resin. The procedure is based on adding a tensile resistant material, glued to the surface that is to be reinforced (Ramos, Casas \& Alarcón, 2004). Tensile mechanical attributes belong to the core concepts in construction and mechanical engineering, materials sciences and solid mechanics. The advances in understanding the elastoplasticity of solids are related to analysing their structure. Correlating the morphological and chemo-physical reactions of solids to external loads is based on understanding their structural components such as crystallites, lattices and atoms. Future materials engineers may be confused as to what is claimed to be a 'structural' reinforcement in the publication presented by Ramos, Casas \& Alarcón (2004). In materials science, the typical reinforcements of the solid structure are achieved by methods such as heat treatments, cold forming and chemical alloying.

In this example, adhesion of the carbon-fibre bands on the surface of construction bars is related to joining two solids. This joint combination results in a synergy in which the bulk 
solid carries the multiaxial compressive stresses, while the thin adhered band of carbon-fibre fabric (another solid) carries higher levels of the tensile stresses (Figure 1). However, the actual structure of the joined components (solids) remains unchanged.

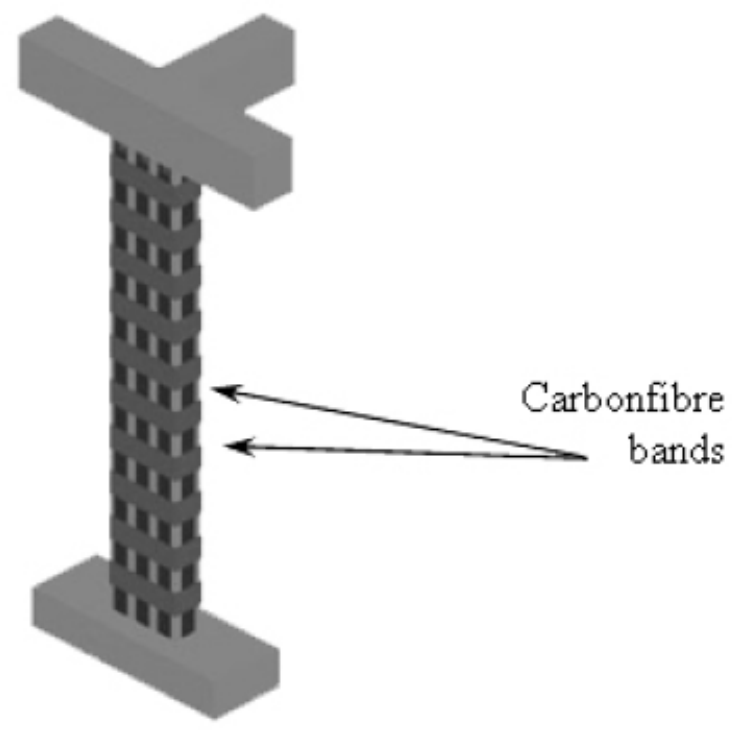

Fig 1: Reinforcements to Bending and Buckling (Freyssinet, 2008)

The development of new construction materials continues on many fronts and so there is a growing imperative that educators avoid confusing the students with inconsistent use of concepts such as 'microstructure', 'macrostructure', 'nanostructure', 'structural steel', 'structural beams' and 'structural reinforcement'. (In the last three examples the word 'structural' is, in any case, superfluous.) Moreover, the concept of 'structure' is often used in contexts with 'texture' and 'morphology'. For example, Allouche \& Monthioux (2005) discuss the 'texture' of deposited layers and the 'formation of morphologies' in the context of material '(micro)structure' where 'structure' denotes "an ideal crystallographic order", while 'texture' refers to "the overall orientation of material stacks". Advanced Materials Associates (2008) define 'microstructure' as 'the size and distribution of individual grains/phases/defects in a solid (e.g., the microstructure of sandstone consists of quartz grains in a calcite matrix)" with a further clarification that a 'microstructure' is "the structure of a polished and etched solid as revealed by a microscope at a magnification greater than 25 50". While Richman et al. (1993) define 'morphology' as "the science of form or structure", Hossein \& Farzaneh (2007) use the term 'morphology' to define the-structure of solids.

Csaba, Garcia-Fuentes \& Alonso (2008) ‘explain' that “...the respiratory region occupies the major part of the nose and is characterised by the presence of shelf-like structures called turbinates..." (Figure 2). Using the term forms (or formations) instead structures could improve the clarity of meaning in such sentences. 


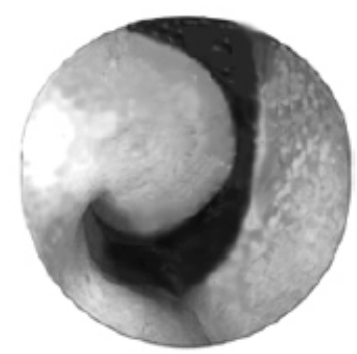

Fig 2: Front Head of Right Inferior Turbinate (Empty Nose Syndrome, 2008)

\section{Logistic}

Numerous academic and engineering disciplines such as management sciences and operations research have adopted the use of the adjective of 'logistic' based on the definition presented in Table 1 (Clause 5). This approach is echoed in scholarly publications (Christopher, 1994), research transcripts (Cooper et al. 1997) and specialist publications such as the Logistics Management Magazine (2008). The conceptual mismatch with definitions presented in Table 1 (Clauses 6 and 7) obstructs the intellectual synergy that should result from knowledge integration. For example, the logistic function finds applications in a range of fields, including artificial neural networks, biology, biomathematics, demography, economics, chemistry, mathematical psychology, probability, sociology and statistics." ("Logistic function" in "Wikipedia", 2009)

\section{Technology}

Homonymous usage of the term 'technology' is notorious in engineering and scientific publications. The difference between the definitions presented in Table 1 (Clauses 9 and 10) allows for differing interpretations of the contexts that include the concept of 'technology'. Numerous international institutions and scientific journals use the term 'technology' to address a 'technique' or a 'system of techniques' (Wikimedia Foundation, 2009; Merriam-Webster, 2008). University of Technology, Sydney (2008) commits to "pursuing best practice in management and technology systems". The Massachusetts Institute of Technology (2008) considers that their mission "is to advance knowledge and educate students in science, technology, and other areas of scholarship". Therefore one can conclude that 'technology' is one of the scholarship areas that can be distinguished from sciences. However, the Delft University of Technology (2008) commits to offering education and research within the technical sciences along with developing technologies for future generations. Here it appears that 'technologies' means 'technical assets and techniques'. There is a significant difference in offering new chemo-physical materialised resources (e.g. tools or equipment) along with the instructions for usage, compared with only offering specific knowledge (e.g. definitions, intelligence and instructions) without supplying any materialised tools, energy or other chemo-physical resources. 


\section{Some Aspects of Mitigating Strategy}

Strategies for improving transparency and transferability of knowledge should draw on the disciplines of didactics, epistemology and ontology (Abhary et al. 2008; Spuzic, Xing, Abhary, 2008). Producing definitions is one of the major tasks in building an ontologically valid knowledge repository (Uschold \& Gruninger, 1996). The mitigating strategy proposed in this transcript is to promote the use of established generic definitions of concepts that are broadly used in various disciplines by adopting a nomenclature hierarchy already established in mathematics, chemophysics and other fundamental sciences. Other concepts can be denoted by introducing new terms to avoid homonymy, synonymy and other ambiguities.

It is unlikely that one language, with its unique vocabulary, can hope to cover the full diversity of human interests. Since English is the lingua franca of science it is clear that an organised system of extension of the scientific nomenclature should be adopted. The multiplication in homonyms can be avoided by using terms from the vocabulary provided by other European languages. We propose that trend of adopting the foreign words in English language be strategically continued. Table 2 presents examples of available terms.

Table 2: Examples of Available Terms

\begin{tabular}{|l|l|l|l|l|}
\hline English & Vector & Structure & Logistic & Technology \\
\hline $\begin{array}{l}\text { Danish \& } \\
\text { Swedish }\end{array}$ & vektor & struktur & logistisk & \multirow{2}{*}{ teknologi } \\
\cline { 3 - 5 } & vector & structuur & logistiska & \\
\hline Futch & vecteur & $\begin{array}{l}\text { structure } \\
\text { (struturer })\end{array}$ & logistique & technologie \\
\hline German & Vektor & Struktur & Logistik & Technologie \\
\hline Italian & vettore & struttura & logistica & tecnologia \\
\hline Portuguese & vetor & estrutura & logística & tecnologia \\
\hline Spanish & vector & estructura & & \\
\hline
\end{tabular}

For example, the concept of 'vector' is well established in mathematics. Definition presented in Table 1 (Clause 2) is concordant with the use listed by the United Nations Multilingual Terminology Database (2005). This definition is also promoted in the ontological approach to engineering disciplines: "The EngMath ontology ... includes conceptual foundations for scalar, vector and tensor quantities..." (Borst \& Akkermans, 1997). The concept defined in Clause 1, Table 1, can be conveniently denominated by using the term 'vecteur' or 'vettore'.

As another example, the concept 'structure' is related to logical and ontological considerations such as the 'part-whole' (mereological concept). We explain what the structure of something is depending of what the purpose (intent) of this definition is. In essence, the concept of 'structure' points at relations within a phenomenon.

Fundamental to this concept is an understanding that objects in space have a certain structure, topography, geometry and other attributes thus allowing for their classification into sets that can be analysed based on selected features (Abhary et al., 2009). The terms 
'structural engineering' and 'structural steel' can be substituted by 'constructional engineering' and 'construction steel'.

As for the concept of 'technology', we suggest to follow an analogy with the nomenclature accepted in numerous other disciplines: biology, geology, tribology, psychology, sociology, anthropology and toxicology describe different branches of science. The English suffix 'logy' or '-ology' denotes a scientific field, and '-ologist' denotes a scientist who studies that field. Thus, we suggest defining 'technology' as shown in Table 1, Clause 8: 'technology' is science of techniques. A hypernym for 'technology' is 'science'.

We propose avoiding the use of the term 'technology' to denote 'techniques'. The usage of the term 'technique' is well known in scientific and engineering publications, (e.g. Amadelli et al., 2005). In special cases such as denoting the branch of engineering that deals with the use of computers and telecommunications to process, retrieve, store and transmit information, rather than using the term 'information technology' we propose using 'information technologie' .

With regard to the adjective 'logistic' we suggest giving priority to the use introduced in mathematics such as the "logistic function". Philosophical concepts can be conveniently addressed using the adjective "logistical".

The adjective "logistic" related to "logistics" could be conveniently substituted by the use of the noun "supply" in the function of an adjective such as used in the expression "supply chain".

Commonly agreed definitions and concepts will reduce wordiness, and simplify the communication of existing knowledge and validation of new discoveries. The Internet should be utilised in this process. Once the theories in one discipline are available to all and transparent to other disciplines, apparently impenetrable conceptual differences will become less confusing and from the depths of our growing knowledge will surface inspiring analogies with the speed of magnetic waves.

\section{Acknowledgement}

Authors are indebted to Dr Denise Wood (University of South Australia) for her helpful comments on an earlier draft of this work.

\section{Conclusions}

This transcript has exposed the challenges associated with attaining mobility and transparency of knowledge across disciplinary fields. The significance of establishing and maintaining unambiguous concepts and non-homonymic nomenclature is in defining knowledge in terms of its application and sharing. Difficulties associated with nomenclature and ambiguous definitions add to increasing misconceptions and decreasing readability. Clear and consistent definitions decrease the information entropy.

Missions of academe include sustaining knowledge shareability and applicability. Authors, editors and educators need to adopt the belief that mobile, shareable and applicable knowledge should be transparent to all disciplines.

The lexical resources of other languages should be used to continue the systematic trend of adopting foreign words into English scientific and engineering nomenclature. Based on such rich lexical base English language can be developed for the transparent and systematic 
expression of scientific and engineering knowledge. This would be helpful for managing knowledge processesing in and across organisations.

\section{References}

Abhary K, et al. 2009, 'Some Basic Aspects of Knowledge', Procedia - Social and Behavioral Sciences, vol. 1, issue 1, pp 1734-1743.

Abhary, A, et al. 2008, Some aspects of defining knowledge, viewed 21 November 2008, <http://epistemic.synthasite.com/>.

Allouche, H \& Monthioux, M 2005, 'Chemical vapor deposition of pyrolytic carbon on carbon nanotubes. Part 2. Texture and structure', Carbon, vol. 43, issue 6, pp. 1265-1278.

Amadelli, $\mathrm{R}$ et al. 2005, 'Photo-electro-chemical properties of $\mathrm{TiO}_{2}$ mediated by the enzyme glucose oxidase', Catalysis Today, vol. 101, issues 3-4, pp. 397-405.

Anand, A, Pugalenthi, G \& Suganthan, PN 2008, 'Predicting protein structural class by SVM with class-wise optimized features and decision probabilities', Journal of Theoretical Biology, vol. 253, Issue 2, pp. 375-380.

Biaggi-Labiosa, A, et al. 2008, 'Tuning the cathodoluminescence of porous silicon films', Journal of Luminescence, vol. 128, issue 3, pp. 321-327.

Borst, P \& Akkermans, H 1997, 'Engineering ontologies', International Journal of Human - Computer Studies, 46, pp. 365 - 406.

Christopher, M 1994, Logistics and Supply Chain Management, Richard D. Irwin, Inc., Financial Times/Prentice Hall, New York.

Cohen, C. Jonathan., 1954, “On the project of a universal character," Mind (New Series) 63: 249.

Cooper, MC et al. 1997, 'Supply Chain Management: More Than a New Name for Logistics, The International Journal of Logistics Management, vol. 8, no. 1, pp. 1-14.

Csaba, N, Garcia-Fuentes, M \& Alonso, MJ 2008, 'Nanoparticles for nasal vaccination', Advanced Drug Delivery Reviews, In Press, Accepted Manuscript.

Elias, EGS 1998, 'Value engineering, A powerful productivity tool', Computers \& Industrial Engineering, vol. 35, Issues 3-4, pp. 381-393.

Giancaspro, J et al. 2009, 'Aerospace technology for strengthening of bridges', Construction and Building Materials, vol. 23, Issue 2, pp. 748-757.

Hossein NS \& Farzaneh A 2007, 'Formation of fine intragranular ferrite in cast plain carbon steel inoculated by titanium oxide nanopowder', Scripta Materialia, vol. 57, issue 10, pp. 937-940.

Hsu, Y, et al. 2008, 'Structure of the Cyclomodulin Cif from Pathogenic Escherichia coli', Journal of Molecular Biology, vol. 384, Issue 2, pp. 465-477.

Klingner, DE, \& Sabet, GM, 2005, 'Knowledge Management, Organizational Learning, Innovation, and Technology Transfer; What They Mean and Why They Matter, Comparative Technology Transfer and Society, vol. 3, no. 3 (December 2005):199-210

Lewis, CI 1960, A Survey of Symbolic Logic, Dover.

$\mathrm{Li}, \mathrm{H}$, \& Chen, Z 2009, 'Design optimization and site matching of direct-drive permanent magnet wind power generator systems', Renewable Energy, vol. 34, Issue 4, pp. 1175-1184.

Perera, $\mathrm{N}$ et al. 2008, 'Rapid identification of virus-carrying mosquitoes using reverse transcriptionloop-mediated isothermal amplification' Journal of Virological Methods, In Press, Corrected Proof.

Ramos, G, Casas, JR \& Alarcón, A 2004, 'Repair and strengthening of segmental bridges using carbon fibers', Engineering Structures, vol. 26, Issue 5, pp. 609-618.

Richman, DB et al. 1993, A Manual of the Grasshoppers of New MexicoOrthoptera: Acrididae and Romaleidae, New Mexico State University Cooperative Extension Service, Las Cruces.

Shadbolt, N, Berners-Lee, T \& Hall, W 2006, 'The Semantic Web Revisited', IEEE Intelligent Systems, vol. 21, Issue 3, pp. 96-101. 
Spuzic, S, Xing, K, Abhary, K 2008, 'Some Examples of Ambiguities in Cross-disciplinary Terminology', The International Journal of Technology, Knowledge and Society, vol. 4, Issue 2, pp.19-28.

Steeman, HJ et al. 2009, 'Modelling indoor air and hygrothermal wall interaction in building simulation: Comparison between CFD and a well-mixed zonal model', Building and Environment, vol. 44, Issue 3, pp. 572-583.

Strawn, GW 1982, 'Technology transfer: What is it? What can it do for me?', Journal of Technology Transfer, vol. 6, no. 2, pp. 45-51.

Uschold, M, Gruninger, M 1996, 'Ontologies: Principles, methods and applications', Knowledge Engineering Review, vol. 11, no. 2, June 1996.

Wagner, W 2006, OT good news A Concrete Step Toward Cleaner Air, 10th November 2006, techarchive.net, Scientific American Partner Network, viewed 3rd November 2008, $<$ http://sci.tech-archive.net/Archive/sci.med.cardiology/2006-11/msg00090.html .

... 2008, Advanced Materials Associates, viewed 28 December 2008 $<$ http://www.advancedmaterialsassoc.com $>$.

... 2008, Delft University of Technology, viewed 25th December 2008, $<\mathrm{http}: / /$ www.vacaturesindelft.nl/overons.php?lang=eng $>$.

... 2008, History of Structural Engineering, University of San Diego, viewed 21 November 2008, $<\mathrm{http}$ ://structures.ucsd.edu/index.php?page=structural_engineering/about_us/history $>$.

... 2008, Logistics Management Magazine, viewed 26 December 2008, $<\mathrm{http}: / /$ www.logisticsmgmt.com/ >.

... 2008, Merriam-Webster Online Search, Merriam-Webster, viewed 16 November 2008, $<\mathrm{http}: / /$ www.m-w.com/>.

... 2008, Mission and origins, Massachusetts Institute of Technology, viewed 25 December 2005, $<$ http://web.mit.edu/facts/mission.html $>$.

... 2008, Our Vision, University of Technology, Sydney, viewed 25 December 2008, $<$ http://www.planning.uts.edu.au/setting/\#OurVision $>$.

... 2008, Repair and strengthening, Freyssinet, viewed 21 November 2008, $<$ http://www.freyssinet.be/4DCGI/an_struct_rehabi_list.htm?120 >.

... 2008, Turbinates tutorial: Turbinate's Anatomy \& Physiology, Empty Nose Syndrome, viewed 13 December 2008, <http://emptynosesyndrome.org/turbinate.html>.

... 2005, United Nations Multilingual Terminology Database - UNTERM, Secretary of the Publications Board, United Nations, New York, viewed 3 November 2005, <http://unterm.un.org/>.

... 2008, What is a structural engineer, Institution of Structural Engineers, The Institution of Structural Engineers, viewed 21 November 2008, <http://www.istructe.org/structuralengineers/db/35.asp $>$.

... 2009, Wikipedia, Wikimedia Foundation, viewed 7 March 2009, <http://en.wikipedia.org>.

... 2009, "Logistic engineering" in "Wikipedia, the free encyclopedia" Wikimedia Foundation, viewed 4th July 2009, <http://en.wikipedia.org/wiki/Logistic_engineering $>$.

... 2009, "Logistic function" in "Wikipedia, the free encyclopedia" Wikimedia Foundation, viewed 4th July 2009, <http://en.wikipedia.org/wiki/Logistic_function>.

... 2009, "Logistics" in "Wikipedia, the free encyclopedia" Wikimedia Foundation, viewed 4th July $2009<$ http://en.wikipedia.org/wiki/Logistics>.

... 2007, "WordNet Bibliography" Cognitive Science Laboratory at Princeton University (2007) viewed 11 May 2009, <http://lit.csci.unt.edu/ wordnet/>.

... 2009, WordNet lexical database for the English language, Cognitive Science Laboratory at Princeton University, viewed 7 March 2009, <http://wordnetweb.princeton.edu/perl/webwn>. 


\section{About the Authors}

\section{K. Abhary}

Dr. Abhary is active in academe since 1975; he educated a few thousand engineers, and acted as a consulting engineer to variety of industries. His publications, exceeding 100, include numerous international journal and conference papers, two handbook chapters, seven book chapters, three books, and a bi-lingual Mechanical Engineering Lexicon. He also published a number of non-technical articles and delivered more than 50 public talks on Australian radios on social, literary and political issues. He has undertaken about 100 engineering projects for industry in Australia, Singapore and Malaysia. He supervised many post-graduated students and has been on the international advisory board of a number of international engineering conferences and journals; associate editor of an engineering journal; reviewer to a number of international engineering journals and conferences, and keynote speaker to international conferences. He was an elected member of the Council of the University of South Australia and a member of Standards-Australia/New Zealand Mechanical Engineering Committee since 1994. He committed himself to "the enhancement of engineers' awareness on social and environmental impact of the Engineering Profession. He is the winner of the Lecturer-of-the-Year-2007 Award, Quality Teaching Award, and Citation for Outstanding Contribution to Students Learning Award of the University of South Australia.

\section{H. K. Adriansen}

University of Aarhus, Denmark; please refer to http://www.dpu.dk/about/hkoa

\section{Prof. F. Begovac}

Professor Dr. Fuad Begovac made numerous engineering and development contributions to manufacturing system in RMK Zenica (now subsidiary of ArcelorMittal, the largest steel company in the world) in addition to his academic career 1970-present at the Faculty of Metallurgy and Materials Science Zenica. His publications are listed at http://www.famm.unze.ba/begovacpub.htm

\section{Z. Kovacic}

Before arriving in New Zealand in 1995, Dr Kovacic was a lecturer in the Belgrade University, Yugoslavia for over fifteen years. He has a $\mathrm{PhD}$ in statistics and has taught a variety of undergraduate and postgraduate statistical courses, as well as computer programming and econometrics. His research interests range from IT education, to eCommerce, time series and multivariate analysis, and other aspects of using computers and communications technologies. He is an Associate Editor of two academically peer refereed journals: Journal of Information Technology Education and Informing Science: The International Journal of an Emerging Transdiscipline.

\section{N. Shpigelman}

Universtiy of Haifa, Israel; please refer to http://carmitnoa.googlepages.com/

\section{Stevens}

Clement Stevens has taught language and literature for most of his career. He has worked within the German and U.K education systems and was Head of Department in a U.K. secondary school for many years. He has cooperated in the production of teaching materials 
and books for both general and technical purposes. He has retired from the position of the Coordinator for Writing on the Orientation English Programme at King Fahd University, Dhahran, Saudi Arabia, and currently works with the Imperial College London.

\section{Dr. S. Spuzic}

Dr Spuzic's industrial experience in design and technology developed in several states both in Europe and Australia. In addition, he has been appointed at a number of universities to teach courses related to design, engineering materials and management. His multi-disciplinary background evolved into an interest in transparent and cross-disciplinary knowledge management. In line with pursuing applied research, he accomplished a number of projects conducted in close collaboration with, and directly funded by industrial systems. Over the recent decade he pursued strategies such teaching-research nexus and online knowledge sharing at several universities. He promotes an open interaction via computerised informationprocessors such as the Internet leading to free access to knowledge. He developed a variety of online teaching sources which can be accessed at http://spuzic.synthasite.com/. Over the recent 25 years he published a series of research papers and presented a number of seminars related to cross-disciplinary issues in university education, design, manufacture and other topics.

\section{Prof. F. Uzunovic}

Professor Faik Uzunovic joined Faculty of Metallurgy and Materials Science Zenica in 1989 to serve in positions of educator, Vice-Dean, Dean and during 2004-2005 as acting Rector of newly constituted University of Zenica. Prior to his academic career he significantly contributed to RMK Zenica (now subsidiary of ArcelorMittal, the largest steel company in the world) both as a manager and technologist. He is registered UNIDO expert (United Nations Industrial Development Organization) and has made numerous research contributions in engineering sciences.

Dr. K. Xing

University of South Australia; please refer to http://people.unisa.edu.au/Ke.Xing 



\section{EDITORS}

Mary Kalantzis, University of Illinois, Urbana-Champaign, USA.

Bill Cope, University of Illinois, Urbana-Champaign, USA.

\section{EDITORIAL ADVISORY BOARD}

Verna Allee, Verna Allee Associates, Martinez, USA.

Zainal Ariffin, Universiti Sains Malaysia, Penang, Malaysia.

Robert Brooks, Monash University, Melbourne, Australia.

Bruce Cronin, University of Greenwich, London, UK.

Rod Dilnutt, William Bethway and Associates, Melbourne, Australia.

Judith Ellis, Enterprise Knowledge, Melbourne, Australia.

Andrea Fried, Technology University Chemnitz, Chemnitz, Germany.

David Gurteen, Gurteen Knowledge, Fleet, UK.

David Hakken, University of Indiana, Bloomington, USA.

Sabine Hoffmann, American University of the Middle East, Kuwait.

Stavros loannides, Pantion University, Athens, Athens, Greece.

Margaret Jackson, RMIT University, Melbourne, Australia.

Paul James, RMIT University, Melbourne, Australia.

Leslie Johnson, University of Greenwich, London, UK.

Eleni Karantzola, University of the Aegean, Rhodes, Greece.

Gerasimos Kouzelis, University of Athens, Athens, Greece.

Krishan Kumar, University of Virginia, Charlottesville, USA.

Martyn Laycock, University of Greenwich; managingtransitions.net, London, UK.

David Lyon, Queens University, Ontario, Canada.

Bill Martin, RMIT University, Melbourne, Australia.

Pumela Msweli-Mbanga, University of Kwazulu-Natal, South Africa.

Alexandra Roth, Northeastern University, Boston, USA.

Claudia Schmitz, Cenandu Learning Agency, Cologne, Germany.

Kirpal Singh, Singapore Management University, Singapore.

Dave Snowden, Cynefin Centre for Organisational Complexity, UK.

Voicu Sucal, Technical University of Cluj-Napoca, Napoca, Romania.

Chryssi Vitsilakis-Soroniatis, University of the Aegean, Rhodes, Greece. JoAnn Wiggins, Walla Walla University, Walla Walla, USA.

Alan Zaremba, Northeastern University, Boston, USA.

Please visit the Journal website at http://www.Management-Journal.com for further information about the Journal or to subscribe. 


\section{THE UNIVERSITY PRESS JOURNALS}

\section{The International
JOURNAL Of the ARTS IN SOCIETY}

Creates a space for dialogue on innovative theories and practices in the arts, and their inter-relationships with society.

ISSN: 1833-1866

http://www.Arts-Journal.com

\section{DESIGN PRINCIPLES \& PRACTICES}

Q:

Examines the meaning and purpose of 'design' while also speaking in grounded ways about the task of design and the use of designed artefacts and processes.

ISSN: 1833-1874

http://www.Design-Journal.com

\section{THE GLOBAL STUDIES JOURNAL}

Maps and interprets new trends and patterns in globalisation.

ISSN 1835-4432

http://www.GlobalStudiesJournal.com

\section{The Intermational OU LEARNING}

Sets out to foster inquiry, invite dialogue and build a body of knowledge on the nature and future of learning.

ISSN: $1447-9540$

http://www.Learning-Journal.com

\section{The Intemanaional ${ }_{\text {JUR }}$ INCLUSIVE MUSEUM}

Addresses the key question: How can the institution of the museum become more inclusive? ISSN 1835-2014

http://www.Museum-Journal.com

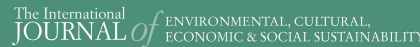

Draws from the various fields and perspectives through which we can address fundamental questions of sustainability.

ISSN: 1832-2077

http://www.Sustainability-Journal.com

\section{UBIQUITOUS LEARNING}

An International Journal

Investigates the affordances for learning in the digital media, in school and throughout everyday life.

ISSN 1835-2030

http://www.ULJournal.com

\section{Tho Intermanional $O f_{\text {ite }} \mathrm{BOOK}$}

Explores the past, present and future of books, publishing, libraries, information, literacy and learning in the information society. ISSN: 1447-9567

http://www.Book-Journal.com

\section{The International
JOURNAL Of DIVERSITY in ORGANISATIONS
COMMUNITIES \& NATIONS}

Provides a forum for discussion and builds a body of knowledge on the forms and dynamics of difference

and diversity.

ISSN: 1447-9583

http://www.Diversity-Journal.com

\section{The Inemational Of in HUMANITIES}

Discusses the role of the humanities in contemplating the future and the human, in an era otherwise dominated by scientific, technical and economic rationalisms.

ISSN: 1447-9559

http://www. Humanities-Journal.com

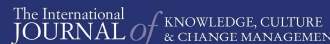

Creates a space for discussion of the nature and future of organisations, in all their forms and manifestations.

ISSN: 1447-9575

http://www.Management-Journal.com

\section{The International}

Discusses disciplinary and interdisciplinary approaches to knowledge creation within and across the various social sciences and between the social, natural and applied sciences. ISSN: 1833-1882

http://www.Socialsciences-Journal.com

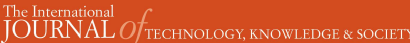

Focuses on a range of critically important themes in the various fields that address the complex and subtle relationships between technology, knowledge and society.

ISSN: 1832-3669

http://www.Technology-Journal.com

\section{JOURNAL of the World Universities Forum}

Explores the meaning and purpose of the academy in times of striking social transformation.

ISSN 1835-2030

http://www.Universities-Journal.com 